\title{
Short Communication \\ First Record of Cyphonotus testaceus (Pallas, 1781) \\ (Coleoptera: Scarabaeidae: Melolonthinae: Melolonthini) from Pakistan
}

\author{
Zubair Ahmed $^{\mathrm{a} *}$, Aleš Bezděk ${ }^{\mathrm{b}}$ and Muhammad Atique Akhter \\ a Department of Zoology, Federal Urdu University of Arts, Science \& Technology, Karachi, Pakistan \\ ${ }^{\mathrm{b}}$ Biology Centre ASCR, Institute of Entomology, Branišovská 31, CZ-370 05 \\ České Budějovice, Czech Republic \\ ${ }^{\mathrm{c}}$ Department of Zoology, University of Karachi, Karachi, Pakistan
}

(received July 11, 2013; revised August 24, 2013; accepted August 29, 2013)

\begin{abstract}
The melolonthine species Cyphonotus testaceus (Pallas, 1781) is for the first time recorded from Pakistan. Geographic distribution of this rarely collected species is summarized. Habitus photo of the male collected in Pakistan is presented.
\end{abstract}

Keywords: Cyphonotus testaceus, new record, melolonthini, palaearctic region, oriental region, Pakistan

Pakistani fauna of chafers belonging to the tribe Melolonthini is still known only insufficiently. Since there is no any comprehensive taxonomic treatment, data about Melolonthini of Pakistan could be extracted from few faunistic papers and/or catalogues only (Bezdik, 2006; Hashmi and Tashfeen, 1992; Chaudhry et al., 1966). The striking exception is quite recent taxonomic contribution on Melolontha of Pakistan (Keith and Saltin, 2012).

The genus Cyphonotus Fischer von Waldheim, 1824 differs from all other Palaearctic and NW Oriental genera of Melolonthini by the following combination of characters: body large and stout (26-40 mm), outer margin of protibia with three strong teeth, subapical calcar of protibia missing in both sexes, clypeus with widely rounded anterior angles, antennal club 4-segmented and very short in both sexes (Baraud, 1992; Medvedev, 1951). Currently, the genus comprises only two valid species (Bezdek, 2006; Nikolaev, 1976; Petrovitz, 1962), insufficiently known C. bicoloratus Petrovitz, 1962 described according to a single female from Iraq, Assur and rather widely distributed C. testaceus (Pallas, 1781). In 2012, the senior author discovered one male specimen of $C$. testaceus in the vicinity of the village Jamaldini in SW Pakistan representing the first record of this chafer for Pakistan.

*Author for correspondence; E-mail zbrahmed36@gmail.com
Material examined. Pakistan (Balochistan province): village Jamaldini $\left(29^{\circ} 33^{\prime} \mathrm{N} 65^{\circ} 59\right.$ 'E, $950 \mathrm{~m}$ a.s.1.), district Nushki, 12. vi. 2012, leg. Shuja Jan, 1 male at light (Fig. 1), deposited in Zubair Ahmed's collection.

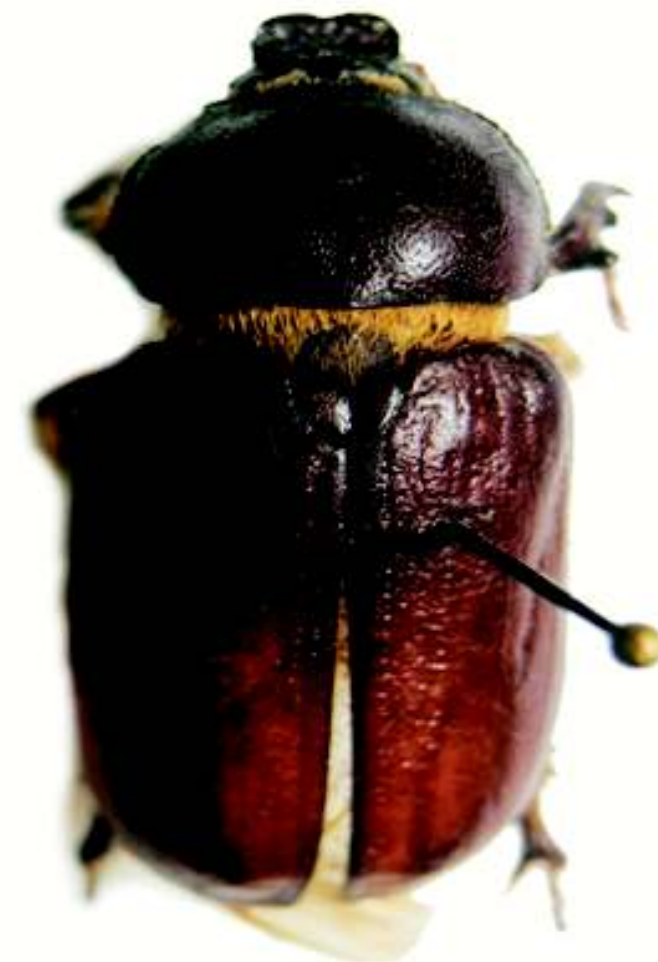

Fig. 1. Habitus photo of the male Cyphonotus testaceus. 
Geographic distribution. C. testaceus is a rather widely distributed species. It is known from eastern Ciscaucasia (lowland of river Terek), eastern Transcaucasia (Armenia and Nakhichivan Auto-nomous Republic) (IablokoffKhnzoryan, 1967), Turkmenistan, Uzbekistan, southern Kazakhstan and Iran (Medvedev, 1951). Moreover, Medvedev (1951) listed it also from Baluchistan, but without more precise data. Here, we report the first reliably confirmed record for Pakistan.

\section{Acknowledgement}

We are grateful to BRSP (Balochistan Rular Support Programme) for providing necessary facilities during the visit of Nushki.

\section{References}

Baraud, J. 1992. Coléoptères Scarabaeoidea D'Europe. Faune de France 78, Lyon, Fédération Française Des Sociétés De Sciences Naturelles \& Société linnéenne de Lyon, ix +856 pp., xi pls.

Bezděk, A. 2006. Scarabaeidae: Melolonthinae: Leucopholini, Macrodactylini, Melolonthini. In: Catalogue of Palaearctic Coleoptera, I. Löbl \& A. Smetana (eds.), vol. 3, pp.190-198, Apollo Books, Stenstrup, Denmark.
Chaudhry, G.U., Chaudhry, M.I., Khan, S.M. 1966. Survey of Insect Fauna of Forests of Pakistan: Final Technical Report, vol. 1, Pakistan Forest Institute, Peshawar, Pakistan.

Hashmi, A.A., Tashfeen, A. 1992. Coleoptera of Pakistan. Proceedings of Pakistan Congress of Zoology, 12: 133-170.

Lablokoff-Khnzoryan, S.M. 1967. Nasekomye Zhestkokrylye. Plastincatousye Fauna Armjanskoj SSR. Izvestiya Akademic Nauk Armjanskoj SSP, Erevan, 6: 1-226.

Keith, D., Saltin, J.P. 2012. Première contribution à la connaissance des Melolontha Fabricius, 1775. du Pakistan (Coleoptera, Scarabaeoidea, Melolonthidae). Revue de l'Association Roussillonnaise d'Entomologie, 21: 20-35.

Medvedev, S.I. 1951. Scarabaeidae. Subfam. Melolonthinae, Part 1, Coleoptera, vol. 10, 514 pp. (Fauna of USSR, New series N. 46).

Nikolaev, G.V. 1976. Neue Synonyme und neue Scarabaidae-Arten aus Turkmenien (Coleoptera). Annales Historico-Naturales Musei Nationalis Hungarici, 68: 164-167.

Petrovitz, R. 1962. Neue und interessante Scarabaeidae aus dem vorderen Orient. I. Teil. Reichenbachia, 1: 107-124. 